\title{
Türkiye Cumhuriyeti Merkez Bankası Finansal Kriz Iletișim Stratejileri
}

\author{
Hale BOZKURT ${ }^{1}$
}

\begin{abstract}
Öz
Global finansal istikrarı etkileyen merkez bankaları para politikası açıklamalarından etkilenen en büyük hedef kitle tüketicilerdir. Tüketicilerin ekonomiye olan güvenleri, merkez bankaları politikalarında belirleyicidir. Merkez bankaları tüketici güvenini, anket çalışmasından oluşan, “Tüketici Güven Endeks-TGE” ile düzenli olarak ölçmektedir.

Bu çalışmada, 2011 Avrupa borç krizi esnasında, TGE'nin azaldığı ve arttığı dönemlerde Türkiye Cumhuriyeti Merkez Bankası (TCMB)'nın kullandığı kriz iletişim stratejileri, Durumsal Kriz Iletişim Teorisi'ne, (Coombs, 2007) göre içerik analiziyle karşılaştırılmıştır.

TCMB'nin kullandığı kriz iletişim stratejileri, kullanılma sıklığına göre; Kriz Engelleyici Eylemleri Bildirme, Kurumun Geçmişte ve Şimdi Yaptığı Güzel Iş̧leri Hatırlatma, Hasarı Az Gösterme, Başkasını Suçlama ve Kendisinin de Kriz Mağduru Olduğunu Söyleme'dir.
\end{abstract}

Anahtar Kelimeler: TCMB, Finansal Kriz İletişimi, Tüketici Güven Endeksi

Atıf: Bozkurt, H. (2020). Türkiye Cumhuriyeti Merkez Bankası Finansal Kriz Iletișim Stratejileri. Akdeniz Üniversi-tesi Iletișim Fakültesi Dergisi, 33, s. 158-177

1 Doç. Dr., Adnan Menderes Üniversitesi, İletişim Fakültesi, Halkla İlişkiler ve Reklamcılık Bölümü, haleboz-kurt24@yahoo.com, ORCID Numarası: 0000-0003-3673-0462. 


\title{
Financial Crisis Communication Strategies of Central Bank of The Republic of Turkey
}

\begin{abstract}
All around the world, central banks' monetary policy implementations and announcements are an important factor affecting global financial stability. Consumers are the biggest target group affected by central bank policies. Therefore, many central banks regularly measure consumer confidence with the "Consumer Confidence IndexCCP', which is a sort of survey.

In this study, the crisis communication strategies used by Central Bank of the Republic of Turkey (CBRT) during the periods of the European debt crisis in 2011 and when the $\mathrm{CCl}$ was increasing were compared by applying content analysis to the Situational Crisis Communication Theory (SCCT), (Coombs, 2007).
\end{abstract}

The crisis communication strategies used by CBRT are as follows (respectively); Corrective Action, Reminder, Justification, Scapegoat, Victimage. There is no statistically significant difference between usage frequencies and crisis communication strategies used by CBRT during periods when $\mathrm{CCl}$ declines and increases.

Keywords: CBRT, Financial Crisis Communication, Consumer Trust Index

\section{Giriș}

A vrupa Birliğine üye ülkelerin bazıları, 2011 yılında, borç krizine sürüklendi. Bu gelişme; önemli sosyal, siyasal ve ekonomik sonuçlara bağlı olarak, Yunanistan, İtalya, Portekiz, İspanya, ve İrlanda'da hükümetlerin değişmesine neden oldu. Avrupa Birliğine üye ülkeler çözüm olarak, kamu harcamalarında kesinti, vergilerde artış, asgari ücret ve kamu çalışanlarının maaşlarını dondurma veya azaltma, verimliliği arttırmak için öncelikle zarar eden kurumlardan başlayarak çalışanları işten çıkarma, kamu kuruluş ve mülklerini satma veya özelleştirme, tasarruf önlemleri açıklama gibi uygulamalara yöneldiler. 2011 Avrupa borç krizi; aynı zamanda merkez bankalarının, görev ve yetkilerinin gelişimi üzerinde de önemli bir etkiye neden oldu.

Ayrıca; Küresel kriz nedeniyle, risk iştahında ve kısa vadeli sermaye akımlarında oynaklığın artmasıyla birlikte, finansal istikrar konusunda giderek artan bir bilinçlilik yaşanması, merkez bankalarının alternatif politikalar aramasına yol açtı. (tcmb.gov. $\operatorname{tr}, 2016)$

Merkez bankalarının temel görevi; bir politika hedefi peşinde ekonomik ortamda parasal koşulların yönetimidir. Parasal koşulların yönetimi için belirlenen merkez bankası politikaları, borç dinamikleri açısından önemli etkilere sahiptir. Bazı politikalar gereksiz yere borç dinamiklerini daha kötüleştirebilir. Örneğin; bir ekonomik durgunluk ortamında, yetersiz olan para politikası, düşük enflasyona neden olabilir ve ekonomik büyü- 
meyi baskılayabilir. Uygun olmayan sıkı para politikası ise hükümet için bir borç krizi yaratabilir. (Orphanides, 2017).

Merkez bankaları, alternatif politikalar arasında, kriz iletişim politikasına daha fazla önem vermeye başlamıştır. Örneğin; TCMB, 2013 yılı para politikası raporunda; faiz oranı, faiz koridoru, likidite yönetimi, zorunlu karşılık oranları ve ROM gibi yeni belirlediği para politikası uygulama araçlarıyla birlikte, para ve kur politikasını güçlendirmek için, gerektiğinde iletişimin destekleyici bir uygulama aracı olarak kullanılacağını bildirmiştir (tcmb.gov.tr, 2016). İletişim, ilk defa TCMB raporunda, para politikası uygulama aracı olarak gösterilmiştir. Diğer ülkelerin merkez bankalarının kriz iletişim stratejilerine baktığımızda, ekonomik özellikleri ve merkez bankalarının yasal statülerindeki farklılıklar nedeniyle, iletişim stratejilerinde de ayrışmalar olduğu görülmektedir.

Örneğin "Amerika Birleşik Devletleri, İngiltere ve Avrupa merkez bankalarının her üçü de, merkez bankası komite toplantılarını takiben, hemen bir basın açıklaması yapmaktadır. Amerika Birleşik Devletleri ve İngiltere merkez bankaları toplantıdan hemen sonra, toplantı tutanaklarını, (hatta Amerika Birleşik Devletleri Merkez Bankası transkriptlerini bile yayınlamakta iken), aksine, Avrupa Merkez Bankası komite toplantılarının tutanaklarını yayınlamamaktadır. Ancak toplantılardan hemen sonra, uzun süreli soru cevap oturumları içeren bir basın konferansı düzenleyerek, ayrıntılı bir açıklama yapmaktadır" (Ehrmann ve Fratzscher, 2007, s.127).

Yine de genel olarak, merkez bankaları arasında ortak iletişim stratejileri oluşmaya başlamıştır. Örneğin; para politikası açıklamalarında gerektiği kadar şeffaf olunması gibi (Van der Cruijsen vd., 2010; Neuenkirch, 2012).

Literatürde; finansal kurumların kriz iletişim politikaları ile ilgili olarak yeterli sayıda makale bulunmakla birlikte, merkez bankalarının kriz iletişim stratejileri ile ilgili sınırlı sayıda makale bulunmaktadır. Bu çalışmalar; daha ziyade merkez bankaları iletişiminin; zamanlaması ve yoğunluğu (Ehrmann ve Fratzscher, 2007), bağımsızlığı (Issing, 1999), şeffaflık derecesi (Blinder, 1998; Geraats, 2002; Woodford, 2005) ve etkinlik derecesiyle (Eijffinger ve Hoeberichts, 2004; Issing, 2005) ilişkilidir.

Ülke ekonomilerinin gelişebilmesi için merkez bankalarının oluşturduğu para politikasının etkili olması gerekmektedir. Para politikasının etkili olabilmesi için ise; gerekli teknik düzenlemelerin yapılması yanı sıra, taraflara doğru şekilde aktarılması da gerekmektedir. Bu nedenle, merkez bankalarının iletişimi son derece önemlidir. Teknik düzenlemeler doğru yapılsa da taraflara aktarımın doğru yapılamaması istenen etkiyi sağlayamayabilir. Günümüzde bazı merkez bankaları, sözle yönlendirme tekniği ile gerekli teknik para politikası düzenlemelerini yapmaksızın bile, sadece yapabilecekleri veya geçmişte yaptıkları düzenlemelerden bahsederek de aynı etkiyi sağlayabilmektedirler. Finansal kriz esnasında tarafların iletişime olan duyarlılıkları arttığı için, kriz iletişimi bir zorunluluk haline gelmektedir. Bu nedenle; merkez bankaları finansal kriz iletişimini yanlış uyguladıkları takdirde, krizin uzamasına ve/veya derinleşmesine, doğru uyguladıklarında ise krizin önlenmesine veya azalmasına neden olabilirler. Hatta kriz nedeniyle artan duyarlılıkları kullanarak, vermek istedikleri mesajları daha kolay aktarıp, krizi avantaja dönüştürebilirler ve imajlarını güçlendirebilirler. Bu nedenlerle özellikle finansal kriz esnasında merkez bankalarının iletişim politikasının nasıl olması 
gerektiğini belirlemek için, uyguladıkları finansal kriz iletişim stratejilerinin de belirlenmesi önemlidir.

"Kriz iletişimi alanına olgu çalışmaları hakimdir" (Commbs, 2007, s.1). Ancak; finansal kuruluşların kullandığı kriz yanıt stratejilerinin neler olduğu konusunda fazla olgu çalışması bulunmamaktadır.

Çalışmamızda; diğer ülke merkez bankaları gibi, finans dünyasının önemli aktörlerinden olan TCMB'nın, 2011 Avrupa Borç Krizinin olumsuz etkilerinden korunmak için, uyguladığı kriz iletişim stratejilerinin neler olduğu sorusuna yanıt aranmaktadır.

İlk kez bu çalışmada; Tüketici Güven Endeksi'ne göre kriz algısının yükseldiği ve azaldığı dönemler arasında, bir merkez bankasının kullandığı kriz iletişim stratejilerinin neler olduğu ve hangi sıklıkta kullandığı, karşılaştırmalı olarak araştırılmaktadır.

\section{Finansal Kriz Iletișimi}

“Kriz; aniden ve beklenmedik şekilde ortaya çıkan, hızlı gelişen, öngörülmesi zor olan, başta mali kayıp, imaj kaybı ve yaşam kaybı, olmak üzere taraflar veya organizasyonlar için ciddi zararlara yol açan veya bu tehditleri oluşturan, halkın veya hedef kitlenin dikkatini çeken acil bir olay veya durum olarak ifade edilebilir" (Li ve Yang, 2010, s.154; http://www.instituteforpr.org). Kriz organizasyonların; ortakları, yöneticileri, çalışanları, projeleri, hedefleri, çalışma düzeni, yatırımları, ürünleri ve markaları ile ilgili oluşabileceği gibi, bu unsurların her birini de etkileyebilmektedir. Coombs'a (2012) göre krizler genel olarak bireyler veya kurumlar için üç konuda hasara yol açabilir. Bunlar; imajın zedelenmesi (Barton, 2001; Dowling, 2002 aktaran Commbs, 2007, s.163), maddi kayıp ve can kaybıdır"

Bir çok kriz çeşidi tanımlanmıştır; finansal kriz, hükümet krizi, mülteci göçmen krizi, çevre felaketi vs,. Borç krizi ise; bir finansal kriz çeşididir. Finansal krizin ve borç krizinin tanımı farklııılar göstermesine karşın, Uluslararası Para Fonu'nun bir (IMF) raporunda aşağıdaki gibi tanımlanmaktadır:

"Finansal kriz kavramının neyi ifade ettiği tartışmalı bir konu olmasına karşın, genel olarak dört tür finansal kriz olduğu ileri sürülmektedir. Para krizi, bankacılık krizi, sistemik finansal kriz ve dış borç krizi. Bir paranın değişim değeri üzerindeki spekülatif saldırı, paranın değer kaybetmesine veya paranın değer kaybetmesini önlemek için, büyük miktarlarda döviz rezervlerinde azalmaya veya faizlerde astronomik düzeylerde yükselmeye neden oluyor ise bu para krizi olarak adlandırılmaktadır. Bankacılık krizi; fiili veya potansiyel banka başarısızlıklarında, bankaların yükümlülüklerini yerine getirmesinin engellemesi veya hükümetin bu başarısızlığı önleyecek müdahaleye zorlanması durumunda ortaya çıkmaktadır. Sistemik finansal krizler, finansal piyasaların etkin olarak çalışmasını engelleyerek, reel ekonomi üzerinde önemli olumsuz etkilere sahip, finansal bozulmalar olarak tanımlanmaktadır. Dış borç krizi ise bir ülkenin dış borcunu ister devlet, isterse özel kesim olsun ödeyememesi durumunda ortaya çıkmaktadır" (IMF, 1998, s.74-75).

Özetle; "tüm finansal kriz türlerinin ortak özelliği, sürdürülemez ekonomik dengesizlik- 
lere ve finansal varlık fiyatlarında (veya döviz kurunda) önemli dalgalanmalara sahip olmasıdır." (Işık vd., 2004, s.48).

\section{Kriz İletișim Stratejileri ve Coombs'un Kriz Iletișim Teorisi}

Halkla ilişkiler literatüründe; kriz iletişimi ile ilgili yayınları kısaca özetleyecek olursak; Marra (Marra, 1998:464) kriz mağduru kurumun, kurum kültürünün ve kriz iletişim stratejisinin başarısını etkileyebileceğini önermiştir. Small (Small, 1991), Fearn-Banks (Fearn-Banks, 1996), Ulmer (Ulmer, 2001) ise kriz iletişimde öncelikli olanın "hızlı olmak, tutarlı olmak ve açık olmak" prensipleri olduğunu ileri sürmüşlerdir. Bu temel prensipler, Coombs (http://www.instituteforpr.org) tarafından da desteklenmektedir. Davis ve Gilman (Davis ve Gilman, 2002, s.32) ise "ileri bir kriz planı olmadığı takdirde, bu çabaların yeteriz kalacağını" önermektedirler.

Özetle; "Halkla ilişkiler literatüründe; kriz iletişimi ile ilgili yayınların, çok büyük bir kısmı; krizi öngörme, krize hazırlanma, kriz yönetim planları geliştirme ve kriz esnasında etkili bir iletişim için pratik öneriler sunma üzerine odaklanmıştır” (Bruce ve Tini, 2008, s.110). Daha küçük bir kısmı ise; kriz iletişim stratejileriyle ilgili olarak, suçlanan organizasyonun özür dileyerek veya bir savunma konuşması yaparak, kendisini temize çıkarma girişimleri ve hasara uğrayan imajını onarma faaliyeti üzerine makalalerden (Benoit, 1995) oluşmaktadır. Allen ve Caillouet'in çalışmaları, kriz yanıt stratejilerinin örgüt tarafından nasıl kullanıldığını sistematik olarak inceleyen ilk makalelerdi. 1995 yılına kadar olan çalışmalar, ilk olarak, Coombs tarafından derlenerek, kriz iletişim stratejileri olarak tanımlandı ve iki yıl sonrasında da Benoit (Benoit, 1997) tarafından yeniden düzenledi ve Imaj Restorasyon Tipolojisi olarak adlandırıldı. Bu şekilde, modellenen kriz iletişimi stratejileri, daha sonraki yıllarda ise, Coombs (2007) tarafından kapsamı genişletilerek, Durumsal Kriz Iletişim Teorisi (DKiT) olarak kavramsallaştırılmıştır. "Günümüzde halkla ilişkiler çalışmalarında en sık kullanılan kriz iletişim stratejileri; Benoit'in (Benoit, 1995, 1997) geliştirdiği Imaj Restorasyon Tipolojisi ve Coombs'un geliştirdiği DKiT'dir" (Avery vd., 2010, s.1). "Ancak, "DKiT; kriz sonrası iletişimle, kaybolan imajın yeniden, nasıl en üst seviyeye yükseltebileceğimizi anlamak için, kanıta dayalı bir çerçeve sunmaktadır" (Coombs, 2007, s.1).

Bu nedenle; bu çalışmada kriz iletişim stratejilerinin irdelenmesinde, Coombs'un (2007) geliştirdiği $D K i T$ tercih edilmiştir. "DKiT, Kriz iletişim stratejilerinin irdelenmes"inde en baskın kullanılan teorilerden birisidir (Avery vd., 2010, s.1; Jin vd., 2011, s. 267).

DKITe göre; stratejiler, genel amacına göre 5 üst sınıfa ve her bir üst sınıfta, en az iki alt sınıfa ayrılmaktadır (Coombs 2007). Tablo 1.de hem tüm stratejiler, hem de her bir iletişim aracındaki ifadenin, hangi strateji sınıfına dahil edildiğini örneklemek için, oluşturduğumuz sanal ifadeler gösterilmektedir. Sanal ifadeler, Tüketici Güven Endeksi'ne göre tasarlanmıştır.

Coombs'un stratejilerini kısaca özetleyecek olursak; Bilgiyi Düzenleme stratejisinin alt sınıflarında, Kriz Engelleyici Eylemleri Bildirme ve Mağdurlara Üzüldügünü Belirtme stratejileri bulunmaktadır. Kriz Engelleyici Eylemleri Bildirme stratejisinde, krizin tekrar oluşmaması için organizasyonun neler yapacağı ve aldığı önlemler anlatılmaktadır. 
Mağdurlara Üzüldüğünü Belirtme stratejisi ise krizin kurbanlarına, krizin neden olduğu hasardan duyulan üzüntünün dile getirilmesidir.

Inkar stratejisi; krizin oluşumunda organizasyonun sorumluluğunu inkar etmeye yönelik bir stratejidir ve üç alt sınıftan oluşmaktadır. Bu alt sınıfta; Suçlayana Saldırma, Kriz Sorumluluğunu Reddetme, ve Başkasını Suçlama stratejileri bulunmaktadır. Suçlayana Saldırma stratejisinde; suçlayan kişi ya da kurumun güvenilirliğini ve imajını zedeleyecek açıklamalarda bulunulmaktadır. Bu şekilde suçlayanın ileri sürdüğü suçun doğru olmayabileceği, dolaylı bir şekilde iddia edilmektedir. Ret stratejisinde ise krizin olmadığı savunulmaktadır. Başkasını Suçlama stratejisinde, krizden başka bir kişi veya kurumun sorumlu olduğu iddia edilmektedir.

Bir diğer üst sınıf strateji; Kriz Sorumluluğunu Azaltma stratejisidir. Kriz Sorumluluğunu Azaltma stratejisinde temel amaç; kriz sorumluluğu ile organizasyonun bağlantısını azaltmaktır ve iki alt sınıf içerir: Art Niyeti Olmadığını veya Yeterli Olamadığını Belirtme, Hasarı Az Gösterme. Art Niyeti Olmadığını veya Yeterli Olamadığını Belirtme stratejisinde; organizasyon, krizi tetikleyen olayı kontrol etmek için gereken bilgi veya deneyimden yoksun olduğunu savunarak veya kötü niyeti olmaksızın krize neden olduğunu iddia ederek, kriz oluşumundaki sorumluluğunu azaltmaya çalışmaktadır. Hasarı Az Gösterme stratejisinde ise; krizin oluşturduğu hasarın, olduğundan daha az olduğu savunulur. Bu amaçla hasarın algılandığı kadar fazla olmadığı veya oluşan hasarın sürekli olmadığı gibi mesajlar verilmeye çalışılır.

Yeniden İmaj Oluşturma üst sınıf stratejisi; krizi oluşturan organizasyonun sorumluluğunu kabul ederek, özür dilediği, bağışlanmayı talep ettiği Özür Dileme stratejisi ile krizin maddi hasarını ödemeyi kabul ettiği Hasarı Karşılama stratejisinden oluşmaktadır.

Imajı Güçlendirme üst sınıf stratejisi; krizden sorumlu tutulan organizasyonun imajını güçlendirme amacını taşımaktadır. Bu amaçla; Kurumun Geçmişte ve Şimdi Yaptığı Güzel Iş̧leri Hatırlatma, Mağdurlara Övgü, ve Kendisinde Kriz Mağduru Olduğunu Söyleme stratejilerinden oluşan üç alt sınıf içermektedir. Kurumun Geçmişte ve Şimdi Yaptığı Güzel Iş̧leri Hatırlatma stratejisinde; taraflara organizasyonun geçmişte yaptığı iyi işler hatırlatılmakta ve mağdurların gözünde zayıflayan imajın güçlendirilmesi hedeflenmektedir. Hatırlatılan işlerin özellikle krizin oluşmasını önleyici işler olması önemlidir. Mağdurlara Övgü stratejisinde ise geçmişte veya şimdi verdikleri destek nedeniyle taraflar övülmektedir. Kendisinde Kriz Mağduru Olduğunu Söyleme stratejisinde ise organizasyonun da kurbanlar arasında olduğu anlatılmaktadır. Ancak Imajı Destekleme stratejilerinin, imajı güçlendirmede minimal katkısı olduğu ve bu nedenle kriz esnasında sekonder strateji olarak kullanılması gerektiği önerilmektedir (Coombs, 2007). 
Tablo 1. Coombs'un (2007) Durumsal Kriz İletişim Stratejileri (Coombs ve Holladay, 2012:40; Weber et. al., 2011:40)

Coombs (2007) Durumsal Kriz Iletişim Stratejileri

\begin{tabular}{|l|l|l|}
\hline Kategori & Strateji & $\begin{array}{l}\text { Kriz iletişim stratejisinin } \\
\text { daha iyi anlaşılabilmesi için } \\
\text { Tüketici güven endeksi üz- } \\
\text { erinden oluşturulmuş sanal } \\
\text { ifadeler }\end{array}$ \\
\hline
\end{tabular}

İlk Uygulanması Önerilen Stratejiler

\begin{tabular}{|c|c|c|}
\hline \multirow[t]{2}{*}{ Bilgiyi Düzenleme } & Kriz Engelleyici Eylemleri Bildirme & $\begin{array}{l}\text { Tüketici Güven Endeksini } \\
\text { arttırmak için TCMB para } \\
\text { politikası uygulamalarında } \\
\text { bazı değişiklikler yapmaya } \\
\text { karar verdi }\end{array}$ \\
\hline & Mağdurlara Üzüldüğünü Belirtme & $\begin{array}{l}\text { TCMB Tüketici Güven } \\
\text { Endeksinin azalmasından } \\
\text { üzülmektedir }\end{array}$ \\
\hline \multicolumn{3}{|l|}{ Ana Stratejiler } \\
\hline \multirow{3}{*}{ Inkar } & Suçlayana Saldırma & $\begin{array}{l}\text { Tüketici Güven İndeksinin } \\
\text { azaldığını söyleyenler, ülke } \\
\text { imajımıza zarar vermek } \\
\text { isteyenlerdir }\end{array}$ \\
\hline & Kriz Sorumluluğunu Reddetme & $\begin{array}{l}\text { Tüketici Güven İndeksinin } \\
\text { azalmasında TCMB'nın hiç } \\
\text { bir sorumluluğu yoktur }\end{array}$ \\
\hline & Başkasını Suçlama & $\begin{array}{l}\text { Tüketici Güven Indeksi,nin } \\
\text { azalma nedeni, Avrupa } \\
\text { Bölgesi Borç Krizidir }\end{array}$ \\
\hline \multirow[t]{2}{*}{$\begin{array}{l}\text { Kriz Sorumluluğunu } \\
\text { Azaltma }\end{array}$} & $\begin{array}{l}\text { Art Niyeti Olmadığını veya Yeterli } \\
\text { Olamadığını Belirtme }\end{array}$ & $\begin{array}{l}\text { TCMB, iyi niyetle ekono- } \\
\text { mik büyümeye katkı } \\
\text { sağlamak amacıyla kısmı } \\
\text { enflasyona izin vermesinin, } \\
\text { Tüketici Güven İndeksini } \\
\text { azaltacağını öngöremedi. }\end{array}$ \\
\hline & HasarıAz Gösterme & $\begin{array}{l}\text { Tüketici Güven İndek- } \\
\text { sinin düşmesi geçici bir } \\
\text { durumdur }\end{array}$ \\
\hline
\end{tabular}




\begin{tabular}{|c|c|c|}
\hline \multirow{2}{*}{$\begin{array}{l}\text { Yeniden İmaj } \\
\text { Oluşturma }\end{array}$} & Hasarı Tazmin & $\begin{array}{l}\text { TCMB Tüketici Güven } \\
\text { İndeksinin bozulması } \\
\text { nedeniyle zarar eden } \\
\text { yatırımcılara tazminat } \\
\text { ödemeyi kabul etti }\end{array}$ \\
\hline & Özür Dileme & $\begin{array}{l}\text { Tüketici Güven Indeksinin } \\
\text { bozulmasından tamamen } \\
\text { TCMB sorumludur ve tüm } \\
\text { mağdurlardan özür dile- } \\
\text { mektedir. }\end{array}$ \\
\hline \multicolumn{3}{|c|}{ Destekleyici Stratejiler } \\
\hline \multirow{3}{*}{ Imajı Güçlenidirme } & $\begin{array}{l}\text { Kurumun Geçmişte ve Şimdi Yaptığı } \\
\text { Güzel İşleri Hatırlatma }\end{array}$ & $\begin{array}{l}\text { TCMB Başkanı, tüketici } \\
\text { güveninde sağladığı artı̧la } \\
\text { geçen ay Dünyanın ve } \\
\text { Avrupa'nın en başarııı } \\
\text { merkez bankası başkanı } \\
\text { seçildi }\end{array}$ \\
\hline & Mağdurlara Övgü & $\begin{array}{l}\text { Tüketici güveni yüksek } \\
\text { yatırımcılarla, TCMB gurur } \\
\text { duymaktadır. }\end{array}$ \\
\hline & $\begin{array}{l}\text { Kendisininde Kriz Mağduru } \\
\text { Olduğunu Söyleme }\end{array}$ & $\begin{array}{l}\text { Tüketici Güven Indeksi sa- } \\
\text { dece Türkiye'de değil, tüm } \\
\text { Avrupa Bölgesinde azaldı. }\end{array}$ \\
\hline
\end{tabular}

Literatürde, organizasyonların kriz iletişiminde, genellikle birden fazla stratejiyi bir arada kullanmayı tercih ettikleri görülmektedir. Örneğin; Toyota marka binek araçlarında, gaz pedalı sorunu nedeniyle oluşan istem dışı hızlanma sonucu kaza riski oluşması ve buna bağlı olarak araç satışlarının düşmesiyle oluşan krizde, sırasıyla; Sessiz Kalma Stratejisi, gaz pedalında sorun olmadığı iddia edilerek Inkar stratejisi, sorunun paspaslardan kaynaklandığı ileri sürülerek, müşterilerin suçlanması ile Başkalarını Suçlama stratejisi ve son olarak da hatanın tekrarlanmaması için araçları servise geri çağırma yolu ile Kriz Engelleyici Eylemleri Bildirme stratejilerinin birlikte kullanıldığı görülmektedir (Finch, 2010). Bir diğer örnekte; Avustralya Erkekler Rugby Liginde ortaya çıkan şike krizinde Kriz Sorumluluğunu Reddetme, Suçlayana Saldırma, Başkasını Suçlama, Kriz Engelleyici Eylemleri Bildirme ve Özür Dileme stratejilerinin kullanıldığı görülmektedir (Bruce ve Tini, 2008). Başarısız kabul edilen diğer bir kriz iletişim örneğinde ise; 2010 yılında British Petroleum şirketine ait Meksika Körfezi petrol çıkarma platformundaki patlama sonucu oluşan ekolojik krizde Coombs'un Özür Dileme stratejisinin kullanıldığı görülmektedir (Wolf ve Mejri, 2013).

Literatürde, bizim çalışmamıza benzer şekilde; finansal kurumların kriz iletişim stratejilerinin irdelendiği iki olgu çalışması bulunmaktadır.

Bu çalışmaların ilkinde; 2008 yılında Amerika Birleşik Devletleri'ndeki finansal kriz esnasında, bankacılık sistemine olan güvenin sarsılmasıyla yaşanan krizde, bir özel ban- 
ka olan Citibank'ın kullandığı kriz iletişim stratejileri, hem Coombs'un (2007) DKiT'ine göre ve hem de Benoit'in (Benoit, 1995) imaj restorasyon tipolojisine göre irdelenmektedir (Weber vd., 2011). Citibank'ın yaşadığı kriz esnasında, Coombs'un DKiT'sine göre kullanılan kriz iletişim stratejileri, sırasıyla; İmajı Güçlendirme (Kurumun Geçmişte ve Şimdi Yaptığı Güzel Işsleri Hatırlatma), Kriz Bilgisini Düzenleme (Kriz Engelleyici Eylemleri Bildirme, Kriz Mağdurlarına Üzüntülerini Belirtme), Inkar (Kriz Sorumluluğunu Reddetme, Suçlayana saldırma, Başkasını Suçlama), Yeniden Imaj Oluşturma (Hasarı Tazmin, Özür Dileme), ve Kriz Sorumluluğunu Azaltma (Art Niyeti Olmadığını veya Yeterli Olamadığını Belirtme, Hasarı Az Gösterme)'dır. Benoit'in (Benoit, 1995) imaj restorasyon tipolojisine göre, kullanılan kriz iletişim stratejileri ise, sırasıyla; Kuruma Yapılan Saldırıları Azaltmaya Çalışma (Kurumun Geçmişte ve Şimdi Yaptığı Güzel Işleri Hatırlatma, Hasarı Az Gösterme, Suçlayana Saldırma), Kriz Engelleyici Eylemleri Bildirme, Inkar (Kriz Sorumluluğunu Reddetme, Başkasını Suçlama), ve Kriz Sorumıuluğunu Azaltma (Art Niyeti Olmadığını veya Yeterli Olamadığını Belirtme, Başkasını Suçlama) ve Krizin Fırsata Çevrildiği Iddiası stratejilerini kapsamaktadır.

Çalışmalardan diğerinde ise; 2000 yılında, Amerika Birleşik Devletleri॰ndeki en büyük doğal gaz dağıtım şirketi olan Enron'un, bazı muhasebe oyunları ve kurulan paravan şirketler aracılığı ile şirket riskleri ve zararları, bilanço dışına çıkarılarak, gerçek mali durumunun gizlenmesiyle oluşan skandalda, muhasebecilik mesleği imaj kaybı krizinde kullanılan iletişim stratejileri irdelenmektedir (Rodgers vd., 2005). Rodney ve arkadaşlarının yaptıkları bu çalışmada; Sertifiye Kamu Muhasebecileri Amerikan Enstitüsü'nün (The American Institute of Certified Public Accountants-AICPA) iletişim araçlarında kullandığı, iletişim stratejileri Benoit'in (Benoit, 1995) imaj restorasyon tipolojisine göre incelenmiştir. Çalışma sonuçlarına göre; Kriz Engelleyici Eylemleri Bildirme, Art Niyeti Olmadığını veya Yeterli Olamadığını Belirtme, Imajı Güçlendirme stratejilerinin kullanıldığı bildirilmektedir.

\section{2011 Avrupa Borç Krizi}

2007 yılının ikinci yarısında, ABD gayrimenkul piyasasında patlak veren ve 2008 Eylül'ünde Lehman Brothers'ın iflasıyla küresel nitelik kazanan finansal kriz, 2009 yılında dünya genelinde hemen hemen tüm ülkelerin ekonomilerinde, son olarakta, 2011 yılında, Avrupa ekonomisinde ciddi daralma meydana getirdi.

Yaşanan küresel kriz, AB ülkelerinde kamu açıkları ve borç stoklarının ciddi boyutlarda artmasına ve birçok üye ülkede kamu maliyesinin sürdürülebilirliğinin tehlikeye girmesine neden oldu. $A B$ üyesi ülkelerin finans ve reel sektörlerinin yüksek entegrasyon düzeyi de ülkelerin birbirinden etkilenme seviyesini ve hızını arttırdı. "Nitekim 2009 sonbaharında Yunanistan`da patlak veren borç krizi, kısa sürede diğer Euro bölgesi ülkelerini ve hatta ekonomik ve parasal birliğin geleceğini tehdit altına soktu" (Featherstone, 2011, s.194). "Başta Almanya olmak üzere, bazı üye ülkelerin Yunanistan'a yardım konusunda isteksiz olması, piyasalarda panik havasının yayılmasına neden oldu ve sonuçta kamu maliyesi ve bankacılık kesimleri sorunlu olan İrlanda, Portekiz, İspanya, İtalya da borç krizine sürüklenme tehdidi ile karşı karşıya kaldı" (Featherstone, 2011, s.194). 
"Borç krizini çözmekte Avrupa Parasal Birliği'nin para ve maliye politikaları etkili olamadı ve tahvil getirilerinde büyük hareketlere sebep olurken Euro ve diğer para birimi kurlarında büyük değişikliklere neden oldu" (Gianviti vd., 2010, s.5).

Ve sonuç olarak; "27 ülkeden oluşan Avrupa Birliği, uzun vadeli nihai hedefi olan siyasi birliğe doğru ilerlerken, gümrük birliği, ortak pazar, ekonomik birlik ve parasal birlik gibi ekonomik bütünleşme (integration) aşamalarında ortak, tek paraya (Avro) geçerek en azından belirli ülkeler arasında "Avro Bölgesi" denilen bir para birliğini sağlamıştı" (Kibritçioğlu, 2011, s.3). Ancak, Maastricht ölçütleri diye bilinen (enflasyon, kamusal bütçe açığı, kamu kesimi borç oranı, faiz haddi ve döviz kuru değişimi ile ilgili yakınlaşma ölçütleri) kriterler ve tek paraya geçilmesi ile ilgili yeni düzenlemelerden, Avrupa borç krizi nedeniyle çok olumsuz etkilendi.

\section{Tüketici Güven Endeksi}

Tüketici Güven Endeksi; Türkiye İstatistik Kurumu (TÜiK) tarafından TÜiK'in resmi web sayfasında metaveri kısmındaki başlıklar altında açıklanmıştır: (TÜiK, 2013, http://www.tuik.gov.tr).

"Tüketici Güven Endeksi ile tüketicilerin kişisel mali durumları, genel ekonomiye ilişkin mevcut durum değerlendirmeleri ve gelecek dönem beklentileri ile yakın gelecekteki harcama ve tasarruf eğilimlerinin anketle ölçülmesi amaçlanmaktadır. Bilgisayar destekli yüz yüze görüşme yöntemiyle anket uygulaması yapılmaktadır. Anketin alan uygulama dönemi her ayın 1-15. günleri arasındadır. Referans ayın anket sonuçları, ilgili ayın son haftasında Ulusal Veri Yayımlama Takvimine göre Tüketici Güven Endeksi Haber Bülteni ile açıklanmaktadır. Türkiye genelinde kent (20,001 ve daha fazla nüfuslu yerleşim yerleri) ve kır (20,000 ve daha az nüfuslu yerleşim yerleri) alanlarında, yeterli sayıda rastgele seçilen hanede, haneyi temsil eden 16 ve daha yukarı yaştaki bir fert kapsanmaktadır. Fert, veri giriş programı tarafından tesadüfi olarak seçilmektedir. Endeksler Avrupa Birliği'nin kullandığı denge yöntemine göre hesaplanmaktadır. Denge, toplam cevap verenlerin içerisinde pozitif ve negatif cevap verenlerin yüzdelerinin farkı alınarak hesaplanmakta ve bu farka 100 eklenerek her bir soru için ayrı yayılma endeksi oluşturulmaktadır. Daha sonra seçilen soruların yayılma endekslerinin aritmetik ortalaması alınarak genel endeks hesaplanmaktadır. Endeks 0 ile 200 aralığında değer almaktadır. Endeksin 100'den büyük olması tüketici güveninde iyimser durum, 100 'den küçük olması tüketici güveninde kötümser durum olduğunu göstermektedir".

\section{Yöntem}

TCMB'nın resmi web sayfasında yayınlanan, 2011 yılına ait, tüm resmi iletişim araçları, kullanılan iletişim stratejileri açısından, Coombs'un DKiT'ne göre içerik analizi ile incelenmiştir. İçerik analizi için, nitel veri analizi yazılımından (Atlas.ti 7.0) faydanılmıştır. Toplam 208 iletişim aracı analiz edilmiştir (Tablo.2). 
Tablo 2. 2011 Yılında TCMB Tarafından Web Sayfasında Bildirilen Resmi İletişim Araçları Ve Sayıları

\begin{tabular}{|l|c|}
\hline TCMB Resmi Illetişim Araçları & Sayı \\
\hline Basın Duyuruları & 91 \\
\hline TCMB Başkanı Konuşmaları ve Sunumları & 27 \\
\hline TCMB Başkan Yardımcıları Konuşma ve Sunumları & 10 \\
\hline Para Politikası Kurulu Üyelerinin Konuşma ve Sunumları & 2 \\
\hline Diğerlerinin Sunumları & 3 \\
\hline Videolar & 10 \\
\hline Teknik Sunumlar & 11 \\
\hline Enflasyon Raporları & 4 \\
\hline Para Politikası Üyeleri Toplantı Kararları ve Özetleri & 24 \\
\hline $\begin{array}{l}\text { Parlamento Plan ve Bütçe Komisyonuna ve Bakanlar } \\
\text { Kurulu'na Yapılan sunumlar }\end{array}$ & 4 \\
\hline Aylık Fiyat Gelişmeleri Raporu & 12 \\
\hline Ödemeler Dengesi Raporu & 4 \\
\hline TCMB Bülteni & 4 \\
\hline Yıllık Rapor & 1 \\
\hline Para Politikası Çıkış Stratejisi Raporu & 1 \\
\hline Toplam & $\mathbf{2 0 8}$ \\
\hline
\end{tabular}

Tablo 2.'de; TCMB'nın belirlediği resmi iletişim araçları ve 2011 yılına ait sayıları bildirilmektedir. Bazı iletişim araçlarının sayısı birbiriyle çakışabilmektedir. Bunun nedeni; para politikası kurulu toplantı kararları ve özetlerinin, aynı zamanda basın duyurusu ile de bildirilmesinden kaynaklanmaktadır.

TCMB'nın resmi iletişim araçları olarak kullandığı video ve metinlerdeki kriz iletişim yapılanmaları (Mc Kee, 2001; Turner, 1997), retrospektif arşiv taraması yöntemiyle elektronik arşivlerden elde edilmiştir.

Çalışma kapsamına; TCMB'nın resmi web sayfasında (http://www.tcmb.gov.tr/) yayınlanan, 2011 yılına ait tüm resmi iletişim araçları dahil edilmiştir. TCMB'nın resmi web sayfasında yer alan, ancak resmi iletişim araçları olarak kabul edilmeyen, diğer iletişim araçları, örneğin, bilimsel araştırmalar çalışma kapsamına alınmamıştır. TCMB tarafından bildirilen resmi iletişim araçları ise şunlardır (Yılmaz, 2010, http://www.tcmb.gov. $\mathrm{tr} / \mathrm{wps} / \mathrm{wcm} / \mathrm{connect/4ee0ea0d-6c7c-435e-8113-49236b4b364f/monetary \_ 2013.pdf?-}$ MOD=AJPERES\&CACHEID=4ee0ea0d-6c7c-435e-8113-49236b4b364f: sayfa 13)

TCMB tarafından, üç ayda bir yayınlanan enflasyon raporu ana iletişim aracı olarak bildirilmektedir. TCMB tarafından bildirilen diğer resmi iletişim araçları ise; yıllık raporlar, para ve kur politikası raporları, altı ayda bir yayınlanan finansal istikrar raporları, Parlamento Plan ve Bütçe Komisyonu'na ve Bakanlar Kurulu'na her altı ayda bir yapılan sunumlar, üç ayda bir yayınlanan bütçe ve ödemeler dengesi raporları, TCMB bültenleri, 
aylık fiyat gelişmeleri raporu, para politikası kurulu toplantı kararları ve özetleri, para politikası çıkış stratejisi raporu, teknik sunumlar, basın duyuruları, konferanslar, TCMB yetkilerinin konuşmaları, sunumları ve basın toplantılarıdır.

\subsection{Araștırmanın Sınırlılıkları}

Çalışmanın sınırlıığı sadece bir merkez bankasının çalışma kapsamına alınmasıdır. Zira; herbir merkez bankasının statüsü, yetki ve sorumlulukları, amaçları veya uğraştıkları sorunlar farklılık göstermektedir. Örneğin; TCMB enflasyonla mücadele ederken, Avrupa Merkez Bankası halen enflasyon yaratmaya çalışmaktadır. Ancak, benzer kriterlere göre sınıflandırma yapılarak, birden çok merkez bankasının çalışma kapsamına alınması, çalışma sonuçlarını zenginleştirebilir. Örneğin cari açık ve yüksek kredi seviyeleri sorunu yaşadığı için gelişmekte olan ülkelerden bazıları (Türkiye, Endonezya, Hindistan, G. Afrika ve Brezilya) bir dönem kırılgan beşli olarak adlandırılmaktaydı. Kırılgan beşli diye tanımlanan diğer ülkelerde de benzer çalışmaların yapılması çalışma sonuçlarını; sebep sonuç ilişkisi üzerinden genelleştirmeyi sağlayabilir.

\subsection{Araștırmanın Soruları}

Bu çalışmanın amacı; 2011 Avrupa borç krizi esnasında TCMB'nın iletişim araçlarında kullandığı kriz iletişim stratejilerini, Coombs ‘un (2007) DKiT’ne göre tanımlamak, kullanılma sıklıklarını belirlemek ve Tüketici Güven Endeksi'ne göre kriz algısının yükseldiği ve azaldığı dönemleri karşılaştırmaktır.

Tüketici Güven Endeksi'nin eksi olduğu dönem, tüketicilerin ülke ekonomisiyle ilgili güvenlerinin kötümser ve kriz algısının yükseldiği dönem, artı olduğu dönem ise tüketicilerin ülke ekonomisiyle ilgili güvenlerinin iyimser ve kriz algısının azaldığı dönem olarak kabul edilmiştir.

Bu amaç çerçevesinde; TCMB'nın kendi resmi iletişim aracı olarak duyurduğu video ve metinler, Coombs'un kriz iletişim stratejileri teorisine göre incelenerek, iki tane araştırma sorusu (AS) belirlenmiş ve bu sorulara yanıt aranmıştır:

AS 1: 2011 Avrupa borç krizi esnasında TCMB; Coombs'un DKiTine göre hangi kriz iletişim stratejilerini kullanmıştır?

AS 2: Tüketici Güven Endeksi'ne göre kriz algısının yükseldiği ve azaldığı dönemler arasında, TCMB'nın kullandığı kriz iletişim stratejileri ve kullanılma sıklıkları açısından istatistiksel olarak anlamlı bir fark var mıdır?

\section{Bulgular}

2011 yılında tüketici güveninin azaldığı ve yükseldiği aylar Tablo 3'de verilmiştir. 
Tablo 3. 2011 yılında Tüketici Güven Endeksi değerleri (Eksi değerler tüketici güvenin azaldığı, artı değerler ise tüketici güveninin arttığı dönemleri göstermektedir.

\begin{tabular}{|c|c|}
\hline Aylar & $\begin{array}{c}\text { Tüketici Güven Endeksinin Bir Öncesi } \\
\text { Aya Göre Değişim Yüzdesi (\%) }\end{array}$ \\
\hline Ocak & 0,4 \\
\hline Şubat & 2,9 \\
\hline Mart & $-0,2$ \\
\hline Nisan & $-0,1$ \\
\hline Mayıs & $-0,8$ \\
\hline Haziran & 4,5 \\
\hline Temmuz & $-1,9$ \\
\hline Ağustos & $-3,8$ \\
\hline Eylül & 2,5 \\
\hline Ekim & $-4,9$ \\
\hline Kasım & 1,7 \\
\hline Aralık & 1,3 \\
\hline
\end{tabular}

Tüketici Güven Endeksi verileri, TÜiK'in resmi web sayfasından (http://www.tuik.gov. tr) alınmıştır

Endeksin 100'den büyük olması; tüketici güvenin iyimser olması ve kriz algısının azaldığı dönem, 100'den küçük olması ise; tüketici güveninde kötümser durum ve kriz algısının yükseldiği dönem olarak belirlenmiştir.

Kriz algısının yükseldiği ve azaldığı dönemler arasında TCMB'nın kullandığı iletişim stratejilerinin sıklıkları arasındaki istatiksel anlamlı farklılık Z- testiyle analiz edilmiştir.

Tablo 3'e göre; 2011 yııının toplam 6 ayında tüketici güveninin azaldığı yani kriz algısının yükseldiği, kalan 6 ayında ise tam tersinin olduğu görülmektedir.

Coombs'un DKiTine göre; alt grup olarak tanımlanmış, toplam 14 kriz iletişim stratejisi bulunmaktadır (Tablo.1). TCMB resmi iletişim araçlarında ise, toplam sekiz kriz iletişim stratejisinin kullanıldığı, başlıca dört tanesinin daha sık kullanılması nedeniyle, ana kriz iletişim stratejisi olarak kabul edildiği görülmektedir. Kullanılma sıklıklarına göre bu ana kriz iletişim stratejileri sırasıyla: Kriz Engelleyici Eylemleri Bildirme, Kurumun Geçmişte ve Şimdi Yaptığı Güzel İşleri Hatırlatma, Hasarı Az Gösterme, ve Başkasını Suçlama stratejileridir. Nadir kullanılan diğer stratejiler ise yine kullanılma sıklıklarına göre; Kendisinde Kriz Mağduru Olduğunu Söyleme, Kriz Sorumluluğunu Reddetme ve eşit sıklıkta kullanılan diğerleri: Art Niyeti Olmadığını veya Yeterli Olamadığını Belirtme ve Özür Dileme stratejileridir. 2011 yılında, tüketici güveninin azaldığı ve yükseldiği dönemlerde, kullanılan kriz iletişim stratejilerinde ve kullanılma sıklıkları arasında istatistiki olarak anlamlı bir fark bulunmadığı belirlenmiştir (Tablo.4.). 
Tablo 4. Tüketici Güven Endeksinin Azaldığı Ve Arttığı Aylarda TCMB Tarafından DKiT’ye Göre Kullanılan Kriz Illetişim Stratejileri Ve Kullanılma Sıklıkları

\begin{tabular}{|c|c|c|c|c|c|}
\hline \multirow{3}{*}{$\begin{array}{l}\text { Coombs'un Durumsal } \\
\text { Kriz iletişim Teorisi } \\
\text { Stratejileri }\end{array}$} & \multicolumn{4}{|c|}{ Dönem } & \multirow{3}{*}{$\mathbf{p}^{\star *}$} \\
\hline & \multicolumn{2}{|c|}{$\begin{array}{c}\text { Tüketici Güven } \\
\text { Endeksinin Azaldığı }\end{array}$} & \multicolumn{2}{|c|}{$\begin{array}{l}\text { Tüketici Güven } \\
\text { Endeksinin Arttığı }\end{array}$} & \\
\hline & $\begin{array}{c}\text { İletişim } \\
\text { Araçlarının } \\
\text { Sayısı* }^{*} \\
(\mathrm{n}=84)\end{array}$ & $\begin{array}{c}\text { Sıklık } \\
(\%)\end{array}$ & $\begin{array}{c}\text { Iletişim } \\
\text { Araçlarının } \\
\text { Sayısı* }^{*}(\mathbf{n = 7 6 )} \\
\end{array}$ & $\begin{array}{c}\text { Sıklık } \\
(\%)\end{array}$ & \\
\hline $\begin{array}{l}\text { Kriz Engelleyici Eylemleri } \\
\text { Bildirme }\end{array}$ & 55 & 0,655 & 48 & 0,632 & 0.761 \\
\hline İnkar & 2 & 0,024 & 1 & 0,0132 & 0.617 \\
\hline Başkasını Suçlama & 35 & 0,417 & 34 & 0,447 & 0.697 \\
\hline $\begin{array}{l}\text { Art Niyeti Olmadığını } \\
\text { veya Yeterli Olamadığını } \\
\text { Belirtme }\end{array}$ & 1 & 0,012 & 0 & 0 & 0.317 \\
\hline HasarıAz Gösterme & 40 & 0,476 & 43 & 0,566 & 0.258 \\
\hline Özür & 0 & 0 & 1 & 0,0132 & 0.317 \\
\hline $\begin{array}{l}\text { Kurumun Geçmişte ve } \\
\text { Şimdi Yaptığı Güzel İşleri } \\
\text { Hatırlatma }\end{array}$ & 48 & 0,571 & 49 & 0,645 & 0.344 \\
\hline $\begin{array}{l}\text { Kendisinde Kriz Mağduru } \\
\text { Olduğunu Söyleme }\end{array}$ & 11 & 0,131 & 10 & 0,132 & 0.991 \\
\hline
\end{tabular}

\section{Tartıșma}

2011 yılı, Avrupa borç krizi esnasında, Türkiye'de, hem tüketici güveninin azaldığı dönemlerde hem de hem tüketici güveninin yükseldiği dönemlerde, TCMB tarafından, resmi iletişim araçlarında, kullanılan ana kriz iletişim stratejileri sırasıyla (Tablo.3) : Kriz Engelleyici Eylemleri Bildirme, Kurumun Geçmişte ve Şimdi Yaptığı Güzel İşleri Hatırlatma, Hasarı Az Gösterme, ve Başkasını Suçlama stratejileridir.

"DKiT, bir krizde yanıt olarak kullanılan ana kriz iletişim stratejilerinin en az yarısının Kriz Engelleyici Eylemleri Bildirme stratejisinden oluşmasını önermektedir" (Coombs ve Holladay, 2012, s.42). Bu çalışmada da, Kriz Engelleyici Eylemleri Bildirme stratejisinin, tüketici güveninin azaldığı ve yükseldiği her iki dönemde de, \%60'dan fazla kullanıldığı görülmektedir. "Genel olarak, farklı kriz çeşitlerinde en çok kullanılan kriz iletişim stratejisi Kriz Engelleyici Eylemleri Bildirme stratejisidir" (Rodgers vd., 2005, s.160). Literatüre göre, finansal kriz esnasında organizasyonların bu stratejiyi kullandığını gösteren, iki adet olgu çalışması bulunmaktadır. Bu olgu çalışmaları; AICPA krizi (Rodgers vd., 2005) ve Citibank krizidir (Weber vd., 2011). TCMB'nın Kriz Engelleyici Eylemleri Bildirme kriz iletişim stratejisini, en sık olarak kullanılmasının nedeni, kişilerarası iletişim ortamlarında, diğer kriz iletişim stratejilerine göre (Özür Dileme stratejisi hariç), daha etkili ve daha uygun olarak algılanması olabilir (Benoit ve Drew, 1997). Merkez Bankası ile tüketiciler arasındaki iletişimden, daha fazlasının tüketiciler arasın- 
da olması çok daha olasıdır. Ancak "Coombs (Coombs, 2006:166, aktaran Commbs ve Schmidt, 2000) ırk ayrımcılığı yasaklarının ihlali gibi bazı kriz çeşitlerinde, bu iki stratejinin, Imajı Güçlendirme gibi destekleyici bir kriz iletişim stratejisinden daha fazla bir etkisi olmadığını bildirmektedir."

TCMB’nın Kriz Engelleyici Eylemleri Bildirme stratejisini kullanmasının diğer nedenleri ise şunlar olabilir:

Birincisi; Michelle ve David (Coombs ve Holladay; 2012, s.286) bir makalesinde "Kriz Engelleyici Eylemleri Bildirme stratejisini, sıklıkla kriz tarihi olan veya kurumsal hata nedeniyle krizde sorumluluğu bulunan kurumların genellikle tercih ettiğini bildirmektedirler." "Bir kurum geçmişinde de, benzer krizler yaşamış ve bu krizlerin oluşumunda da sorumluluğu bulunuyorsa, kurumun bir kriz öyküsü var demektir ve bu durum, sonraki her bir krizde, krizden kaynaklanan tehdidin daha da artmasına neden olur" (Coombs ve Holladay; 2012, s.39).

TCMB’nın kriz geçmişinin, olumlu olduğu söylenemez. Ayrıca Dönemin Başbakanı, Recep Tayyip Erdoğan; "faiz lobisi" kavramını ortaya atmış ve faizlerin indirilmesine karşı gelen her kesimin (TCBM de dahil) finansal krizin oluşumunda sorumluluğu olduğunu iddia etmiştir. TCMB'nın kriz oluşumundan kısmen sorumlu tutulması nedeniyle, Kriz Engelleyici Eylemleri Bildirme stratejisini kullanması literatürle uyumlu bulunmuştur.

İkincisi; bir kriz bilgi gereksinimi yaratır. Krizin belirsizliği paydaşlar için stres kaynağıdır. Paydaşların bu psikolojik stresle başa çıkabilmeleri ve benzer krizlerden korunabilmeleri için hangi kriz engelleyici eylemlerin alındığına ilişkin bilgi gereksinimleri ortaya çıkar. "Kriz Engelleyici Eylemleri Bildirme stratejisininin kullanılması paydaşları güvence altına alır ve böylece psikolojik streslerini (Coombs ve Holladay; 2012, s.163; Coombs, 2007, s.165, alıntı: Sellnow vd., 1998). TCMB'da; psikolojik algı ile bire bir ilişkili olan tüketici güven endeksini yükseltmek için tüketiciler üzerindeki psikolojik stresi azaltmak istemiş olabilir.

TCMB tarafından en sık kullanılan ikinci ana iletişim stratejisi Kurumun Geçmişte ve Şimdi Yaptığı Güzel Iş̧leri Hatırlatma stratejisidir“. Commbs (Commbs, 2007, s.170; Coombs ve Holladay; 2012, s.42) Kurumun Geçmişte ve Şimdi Yaptığı Güzel Iş̧leri Hatırlatma stratejisinin, bir ana strateji olarak kullanılmamasını, üç ana stratejiden (Inkar, Kriz Sorumluluğunu Azaltma, Yeniden Imaj Oluşturma) en az birisiyle birlikte, destekleyici bir strateji olarak kullanılmasını önermektedir". "Ayrıca; Imaj Güçlendirme (Kurumun Geçmişte ve Şimdi Yaptığı Güzel Işsleri Hatırlatma, Kendisinde Kriz Mağduru Olduğunu Söyleme, Mağdurlara Övgü) stratejilerinin, yalnızca bir organizasyonun geçmişinde iyi işler yapmış olması ve/veya başkalarına teşekkür etme nedenleri olduğunda kullanılabileceğini bildirmektedir" (Coombs ve Holladay; 2012, s. 41). Bu nedenle, TCMB, Kurumun Geçmişte ve Şimdi Yaptığı Güzel İşleri Hatırlatma stratejisini destekleyici olarak değil, ana iletişim stratejilerinden birisi olarak kullandığı için, literatürle çelişmektedir. “Türkiye Cumhuriyeti 1920’li yıllardan beri enflasyonla mücadele etmektedir ve TCMB para politikaları enflasyonu önlemede pek yeterli olmamıştır. Ancak, TCMB'nın, 2006 yılından itibaren, "Enflasyon Hedeflemesi Rejimi'he geçmesi sonrası, başarılı uygulamaları, uluslararası finans çevrelerinde takdir kazanmıştır" 
(TCMB, Basın Duyurusu, 15 Ekim 2008) ve Türkiye'nin kredi notu, saygın kredi kuruluşlarınca, tarihinde ilk kez, yatıım yapılabilir seviyelere arttırılmıştır. Financial Times Gazetesi'nin çıkardığı saygın bir finans dergisi olan Banker (The Banker, 2013), TCMB Başkanı Erdem Başçı'yı Dünyanın ve Avrupa'nın en başarılı merkez bankası başkanı seçmiştir. Bu nedenle, TCMB'nin uzak geçmişindeki hatalarını örtmeye yönelik olarak, yakın geçmişindeki iyi işleri sıklıkla hatırlatarak, Kurumun Geçmişte ve Şimdi Yaptığı Güzel Işsleri Hatırlatma stratejisini ana iletişim stratejisi olarak kullandığı düşünülebilir.

TCMB'nin en sık kullandığı üçüncü ana iletişim stratejisi ise Hasarı Az Gösterme stratejisidir. Hasarı Az Gösterme stratejisi, algılanan hasarın aslında daha az olduğunu vurgulama girişimidir ve kriz ile organizasyon arasındaki bağlantıyı azaltmak için kullanılmaktadır. TCMB'nın da algılanan hasarı azaltmak için çeşitli söylemler kullandığı görülmektedir. Bu söylemlerden bazıları şunlardır: "Enflasyondaki artış geçicidir", "Artan döviz kurunun enflasyona geçişkenliği çok azdır”, "Enflasyonun büyümeye olumsuz etkisi sınırlı olmuştur" gibi. Commbs; kriz esnasında, Hasarı Az Gösterme stratejisini; daha önce taraflarla pozitif bir ilişki geçmişi olan kurumların kullanmasını önermektedir. Oysa, tarafların TCMB ile pozitif bir ilişki geçmişi bulunmamaktadır. Ancak "Brown ve White (Brown ve White, 2011, s.75) bir çalışmasında; Hasarı Az Gösterme stratejisini kullanan kurumların taraflarla pozitif geçmişinin olmasının, krizdeki sorumluluğunu azaltıcı bir etki oluşturmadığını belirtmektedir”. Bu nedenle; TCMB'nın finansal kriz esnasında Hasarı Az Gösterme iletişim stratejisini kullanmasının literatürle uyumu tartışmalıdır.

TCMB'nin en sık kullandığı dördüncü ana iletişim stratejisi ise; Başkasını Suçlama stratejisidir. Coombs, bu stratejinin kurumun krize katkısı yüksek oranda değilse, kullanılmasını önermektedir. Zira; TCMB'nin Tüketici Güven Endeksi'nin azalmasındaki rolü ikincildir. Asıl neden; Avrupa Bölgesi borç krizidir. Bu nedenle, TCMB'nın Başkasını Suçlama stratejisini kullanması literatürle uyumlu bulunmuştur. Ancak, "Brown ve White (Brown ve White, 2011, s.75) çalışmalarında; Başkasını Suçlama stratejisini kullanan kurumların, taraflarla geçmişinin; pozitif olmasının krizdeki sorumluğunu anlamlı şekilde azalttığını, negatif olmasının ise tam tersi arttırdığını ifade etmektedir". Bu durumda; TCMB'nın genelde kötü geçmişi nedeniyle, Başkasını Suçlama iletişim stratejisini kullanması literatürle çelişkili bulunmuştur.

TCMB tarafından nadiren kullanılan, bir başka deyişle destekleyici olarak kullandığı diğer kriz iletişim stratejileri ise: Kendisinde Kriz Mağduru Olduğunu Söyleme, Kriz Sorumluluğunu Reddetme, Art Niyeti Olmadığını veya Yeterli Olamadığını Belirtme, ve Özür Dileme stratejileridir. Kendisinde Kriz Mağduru Olduğunu Söyleme stratejisi ise \%10'un üzerinde sıklıkta TCMB tarafından iletişim araçlarında kullanıımıştır. Kendisinde Kriz Mağduru Olduğunu Söyleme stratejisine göre, TCMB kendisinin krizin mağdurları arasında yer aldığını iddia etmektedir. Gerçekten de; 2011 Avrupa Birliği Borç Krizi, Avrupa Birliği Para Birimi Euro'nun uluslararası rezerv para birimi olması nedeniyle, Avrupa ülkelerinin yanı sıra diğer ülkeleri de etkilemiştir. Özellikle ihracatının büyük kısmını Avrupa'ya yapan ülkeler krizden daha fazla etkilenmişlerdir.Türkiye ihracatının en büyük kısmını Avrupa Birliği ülkelerine yapmaktadır. Türkiye ihracatının azalması, mevcut cari açık sorunun artmasına neden olmuş ve sonuçta Tüketici Güven Endeksi'nin azalmasına yol açmıştır. Coombs kurumun Kendisininde Mağdur Olduğunu 
Söyleme stratejisinin, kurumun imajını desteklemede minimal etkisi olduğu için destekleyici veya sekonder iletişim stratejisi olarak kullanılmasını önermektedir.TCMB'nın Kendisinin de Kriz Mağduru Olduğunu Söyleme iletişim stratejisini destekleyici olarak kullanması nedeniyle literatürle uyumlu bulunmuştur.

Kendisinde Kriz Mağduru Olduğunu Söyleme stratejisi dışındaki, diğer destekleyici stratejilerin kullanılma sıklıklarının, çok düşük (\%1'e yakın) olması nedeniyle, kriz iletişimine minimal katkısı olacağı düşünüldüğünden, literatürle uyumu değerlendirilmemiştir.

\section{Sonuc,}

2011 Avrupa borç krizi esnasında, tüketici güvenin azaldığı ve yükseldiği dönemlerde, TCMB'nın, DKiTe göre kullandığı kriz iletişim stratejileri, karşılaştırıldığında; TCMB >nin her iki dönemde de, aynı kriz iletişim stratejilerini, aynı sıklıkta kullandığı görülmektedir. Bunlardan bazılarının daha sık olarak kullanılması nedeniyle, ana kriz iletişim stratejisi olarak, kalanların ise daha az kullanılmaları nedeniyle, destekleyici kriz iletişim stratejisi olarak tercih edildiği görülmektedir. Ana iletişim stratejileri; Kriz Engelleyici Eylemleri Bildirme, Kurumun Geçmişte ve Şimdi Yaptığı Güzel İşleri Hatırlatma, Hasarı Az Gösterme, ve Başkasını Suçlama stratejileridir. Destekleyici kriz iletişim stratejileri ise yine kullanılma sıklıklarına göre; Kendisinde Kriz Mağduru Olduğunu Söyleme, Kriz Sorumluluğunu Reddetme ve eşit sıklıkta kullanılan diğerleri: Art Niyeti Olmadığını veya Yeterli Olamadığını Belirtme ve Özür Dileme stratejileridir. TCMB'nın; Kriz Engelleyici Eylemleri Bildirme, ve Kendisinin de Kriz Mağduru Olduğunu Söyleme stratejilerini kullanması literatürle uyumlu, Hasarı Az Gösterme stratejisinin kullanması literatürle tartışmalı, Kurumun Geçmişte ve Şimdi Yaptığı Güzel Iş̧leri Hatırlatma, Başkasını Suçlama iletişim stratejisini kullanması ise literatürle uyumsuz bulunmuştur. Kriz Sorumluluğunu Reddetme, Art Niyeti Olmadığını veya Yeterli Olamadığını Belirtme ve Özür Dileme kriz iletişim stratejilerinin kullanımının literatürle uyumu, kullanılma sıklıklarının çok az olması nedeniyle, anlamlı olmayacağından değerlendirilmemiştir.

TCMB'nın tüketici güveninin azaldığı ve artıı̆ı dönemlerin her ikisinde de aynı iletişim stratejilerini ve aynı sıklıkta kullanması ise iki avantaj sağlayabilir. Birincisi; kriz esnasında kullandığı iletişim stratejilerini, kriz olmayan dönemde de kullanması, tüketicilerin bu kriz iletişim stratejilerine aşina olmasını sağlayarak, hafızalarda kalıcılığını arttırabilir ve kriz esnasında verdiği mesajların tüketicilere geçirgenliğini arttırabilir. İkincisi ise; kriz esnasında kriz olmayan döneme göre farklı bir iletişim stratejisinin kullanılmaması veya kullanılan iletişim stratejilerinin sıklığında anlamlı bir fark olmaması, değişen farklı bir durum yok algısı yaratarak, tüketicilere güven sağlayabilir ve ülke ekonomisinde bir istikrar var algısı oluşturabilir.

Ancak, bu sonuçların farklı çalışmalarla araştırılması gerekmektedir. Merkez bankalarının kriz iletişim stratejilerinin, akademik literatürle uyumlu olarak belirlenmesi veya belirlenmemesi durumunda tüketici güvenini nasıl etkilediği benzer çalışmalarla araştırılmalıdır. Benzer çalışmaların yapılması merkez bankaları için kriz esnasında hangi stratejilerin çalıştığını görmemize ve merkez bankalarına özel bir kriz iletişim politikası 
belirlenmesine katkı sağlayabilir. Bu tip çalışmalar; kriz esnasında oluşturulacak iletişim stratejilerine; rehberlik konusunda destek sağlayacaktır.

\section{Kaynakça}

Avery, A.J., Lariscy, R.W., Kim, S. \& Hocke, T. (2010). A Quantitative Review of Crisis Communication Research in Public Relations from 1991 to 2009, Public Relations Review 36, 190-92. http://dx.doi.org/10.1016/j.pubrev.2010.01.001.

Orphanides, Athanasios, Central Bank Policies and the Debt Trap MIT Sloan Research Paper No. 5187-17. 0 6.02. 2017 tarihinde SSRN: https://ssrn.com/abstract=2912609 adresinden edinilmiştir.

Central Bank Governor of the Year 2013. (2013). The Banker, The Banker Editors 02/01/2013 tarihinde http://www.thebanker.com/Awards/Central-Bank-Governor-of-the-Year/Central-BankGovernor-of-the-Year-2013 adresinden edinilmiştir.

Barton, L. (2001). Crisis in Organizations II , 2nd edn., South-Western, Cincinnati, OH, College Divisions,

Benoit, W.,L. (1995). Accounts, Excuses, and Apologies: A Theory Of Image Restoration. Albany, NY: State University of New York Press.

Benoit,W. L. (1997). Image Repair Discourse and Crisis Communication.Public Relations Review, 23, 177-186.

Blinder, A. (1998).Central Banking in Theory and Practice, Cambridge MA., MIT Press,

Brown, A. K. \& White, L. C. (2011). Organization-Public Relationships and Crisis Response Strategies: Impact on Attribution of Responsibility. Journal of Public Relations Research, 23 (1), 75-92.

Bruce, T.\&Tini, T. (2008). Unique Crisis Response Strategies In Sports Public Relations: Rugby League and The Case For Diversion, Public Relations Review [serial online]. June;34(2):108115.

http://www.instituteforpr.org/crisis-management-and-communications 10.12.2016 tarihinde edinilmiştir.

http://www.tcmb.gov.tr/wps/wcm/connect/4ee0ea0d-6c7c-435e-8113-49236b4b364f/ monetary_2013.pdf?MOD=AJPERES\&CACHEID=4ee0ea0d-6c7c-435e-8113-49236b4b364f, 10.09.2016 tarihinde edinilmiştir.

Coombs,W. T. (2007). Crisis management: A Communicative Approach. In C. H. Botan \& V. Hazleton (Eds.), Public Relations Theory II (pp. 171-197). Mahwah, NJ: Lawrence Erlbaum Associates.

Coombs, W.T. (2007). Protecting Organization

Reputations During a Crisis: The Development and Application of Situational Crisis Communication Theory. Corporate Reputation Review, 10 (3), 163-176. 
Coombs W.T. (2012). Ongoing Crisis Communication: Planning, Managing, and Responding (3rd. ed). Thousand Oaks, CA: Sage Publications.

Coombs, W.T. \& Holladay, S.J. (2012). The Handbook of Crisis Communication. Chichester, U.K.; Malden, MA: Wiley-Blackwell.

Commbs, W, T., \& Schmidt, L. (2000).An Empirical Analysis Of Image Restoration: Texaco's Racism Crisis. Journal of Public Relations Research, 12, 163-178.

Davis, S. C. \& Gilman, A. D. (2002).Communication Coordination.Risk Management, 49(8), 38-42.

De Wolf, D. \& Mejri, M. (2013). Crisis Communication Failures: The BP Case Study. International Journal of Advances in Management and Economics, 2 (2), 48-56.

Dowling, G. (2002). Creating Corporate Reputations: Identity, Image, and Performance, Oxford University Press, New York.

Ehrmann, M. ve Fratzscher, M. (2007), "The Timing of Central Bank Communication", European Journal of Political Economy, 23, 124-145.

Eijffinger, S. \& Hoeberichts, M. (2004). Central Bank Communication and Output Stabilization. CEPR Discussion Paper, vol. 4408. CEPR, London.

Featherstone, K. (2011). The JCMS Annual Lecture: The Greek Sovereign Debt Crisis and EMU: A Failing State in a Skewed Regime. Journal of Common Market Studies, 49, 2, 193-217

Fearn-Banks, K. (1996). Crisis communications: A Case Book Approach. Mahwah, NJ: Lawrence Erlbaum Associates.

Geraats, P. (2002). Central Bank

Transparency.Economic Journal 112, F532-F565.

Gianviti, F., Krueger, A.O., Ferry J.P., Sapir, A. \& Von Hagen, J. (2010).A European Mechanism for Sovereign Debt Crisis Resolution: A Proposal

IMF (1998).World Economic Outlook, 74-75.

Issing, O. (2005). Communication, Transparency, Accountability: Monetary Policy in the TwentyFirst Century. Federal Reserve Bank of St. Louis Review 87, 65-83.

Issing, O. (1999). The Eurosystem: Transparent and Accountable, or Willem in Euroland. Journal of Common Market Studies, 37, 503-519.

Işık, S., Duman, K.\& Korkmaz, A. (2004). Türkiye Ekonomisinde Finansal Krizler: Bir Faktör Analizi Uygulaması. D.E.Ü. i.i.B.F. Dergisi, (19)1, 45-69.

Jin Y, Pang P \& Cameron T. G. (2011). Toward a Publics-Driven, Emotion-Based Conceptualization in Crisis Communication: Unearthing Dominant Emotions in Multi-Staged Testing of the Integrated Crisis Mapping (ICM) Model. Journal of Public Relations Research, 24, 266-298.

Kibritçioğlu, A. (2011). Avro Bölgesi Ülkelerindeki Güncel Borç Krizi, Iktisat ve Toplum Dergisi, 10, Ağustos, 30-41. 
Li H.\& Yang C. (2010). How Financial Enterprises Deal with Crisis Public Relation. Asian Social Science, 11(6):154-158.

McKee, A. (2001). A Beginner's Guide to Textual Analysis.Metro (Film, Television, Radio, Multimedia), 127/128, 138-149.

Rodgers K, Dillard J \& Yuthas K. (2005). The Accounting Profession: Substantive Change and/ or Image Management. Journal of Business Ethics.58,159-176.

Sellnow , T . L ., Ulmer , R . R . and Snider , M . ( 1998 ) The Compatibility of Corrective Action in Organizational Crisis Communication, Communication Quarterly, 46 , 60-74 .

Small,W. (1991). Exxon Valdez: How to Spend Billions and Still Get a Black Eye. Public Relations Review, 17(1), 9-26.

TCMB, Basın Duyurusu, 15 Ekim 2008 tarihinde http://www.tcmb.gov.tr/yeni/announce/2008/ ANO2008-26.htm adresinden edinilmiştir.

Turner, G. (1997). Media Texts and Messages. In S. Cunningham \& G. Turner (Eds.), The Media in Australia: Industries, Texts, Audiences (2nd ed.) St. Leonards: Allen \& Unwin. (pp. 293-347).

TÜIK, (2013).Tüketici Güven Endeksi, Temmuz 2013.Sayı: 13554, 29 Temmuz 2013. Tarihinde http://www.tuik.gov.tr /PreHaberBultenleri.do?id=13554 adresinden edinilmiştir.

Ulmer, R. (2001).Effective Crisis Management Through Established Stakeholder Relationships. Management Communication Quarterly, 14(4), 590-615.

Van der Cruijsen, C., Eijffinger, S., \& Hoogduin, L., (2010). Optimal Central Bank Transparency. Journal of International Money and Finance, 29, 1482-1507

Weber, M., Erickson L.S. \& Stone, M. (2011). Corporate Reputation Management: Citibank's Use of Image Restoration Strategies During the U.S. Banking Crisis. Journal of Organizational Culture, Communications and Conflict, 15, (2) 53-55.

Woodford, M. (2005).Central-bank Communication and Policy Effectiveness. NBERWorking Paper, vol. 11898. National Bureau of Economic Research, Cambridge MA.

Yılmaz, D. (2010). , 10.09.2016 tarihinde http://www.tcmb.gov.tr/yeni/duyuru/2010/Baskan_ Usak2010.pdf adresinden edinilmiştir. 